\title{
ATITUDES ETNOLINGUÍSTICAS DO POVO \\ TAPUIA DO CARRETÃO (GO) E SUA RELAÇÃO \\ COM A ATUAÇÃO DOS PROFESSORES \\ INDÍGENAS NO CONTEXTO DE SUAS \\ PESQUISAS E DIFERENTES PRÁTICAS \\ PEDAGÓGICAS INTERCULTURAIS
}

\author{
NAZÁRIO*, Maria de Lurdes \\ Universidade Estadual de Goiás (UEG)
}

\section{RESUMO}

Nosso objetivo é problematizar as atitudes do povo Tapuia em relação à sua identidade indígena tão questionada, por possuir um fenótipo afroindígena e fazer uso da língua portuguesa, colocando em foco impactos positivos que observamos na comunidade decorrentes da atuação de seus professores indígenas no contexto de suas pesquisas e outras práticas pedagógicas durante sua formação na licenciatura em Educação Intercultural do Núcleo Takinahakỹ de Formação Superior Indígena da Universidade Federal de Goiás. Compreendemos que os professores Tapuia junto com seu povo vêm se conscientizando, nos termos de Paulo Freire (1987), de sua realidade de opressão histórica, havendo a valorização de sua identidade diferenciada, a melhora em sua autoestima e a potencialização de sua atitude etnolinguística positiva.

Palavras-chave: Povo Tapuia. Identidade. Atitudes Etnolinguísticas. Educação Intercultural.

\section{ABSTRACT}

Our aim is to problematize the attitudes of the Tapuia people in relation to their so questioned indigenous identity, for having an Afroindigenous phenotype and for making use of the Portuguese language, placing in focus positive impacts that we observe in the community resulting from the actions of its indigenous teachers in the context of his researches and other pedagogical practices during their teacher developmente in Intercultural Education of the Nucleus Takinahakỹ of Indigenous Pre-service Education of the Federal University of Goiás (UFG). We understand that the Tapuia teachers and their people have become aware, in the terms of Paulo Freire 
(1987), of their reality of historical oppression, with the valorization of their differentiated identity, the improvement in their self-esteem and the enhancement of their positive ethnolinguistic attitude.

Key words: Tapuia people. Identity. Ethnolinguistic Attitudes. Intercultural Education.

\section{INTRODUÇÃO}

Nosso objetivo é problematizar as atitudes do povo Tapuia em relação à sua identidade indígena tão questionada, por possuir um fenótipo afroindígena e fazer uso da língua portuguesa (LP), colocando em foco a atuação de seus professores indígenas no contexto de suas pesquisas e outras práticas pedagógicas durante sua formação na licenciatura em Educação Intercultural do Núcleo Takinahakỹ de Formação Superior Indígena da Universidade Federal de Goiás (UFG).

Conceitualmente, a atitude é compreendida como uma maneira de pensar, sentir e agir, positiva ou negativamente, em relação a problemas, pessoas, grupos, situações sociais (LAMBERT \& LAMBERT, [1966] 1975, p. 100). Decorrente e constituidora das avaliações sociais historicamente situadas, a atitude é um conceito abrangente que nos remete, por exemplo, à avaliação subjetiva que alguém ou grupo social faz de si e do outro por meio da linguagem, do discurso e são compartilhadas em uma comunidade. Nesse sentido, "a atitude está associada ao lugar de pertencimento sóciohistórico e aos vínculos sociais e culturais dos sujeitos" (REZENDE, 2013). Nesta pesquisa, compreendemos a atitude dos Tapuia como etnolinguística por estarmos colocando em discussão atitudes que se dão no contexto de uma situação social e cultural específica daqueles que têm visto sua identidade indígena questionada e negada pelos de fora da comunidade em função do uso do português, mas também pelo fenótipo afroindígena.

Os Tapuia são herdeiros dos índios Xavante, Kayapó e Karajá/ Javaé aldeados no aldeamento Pedro III (fundado em 1788 em terras goianas), tendo surgido do casamento de duas índias, Xavante e Kayapó, com dois negros da região. Vivem na Terra Indígena Carretão, nos municípios de Rubiataba e Nova América (GO), área do antigo aldeamento. No século XX, passaram por décadas de muita perseguição, sofrimento e dificuldades de sobrevivência, 
com suas famílias ilhadas em pequenas porções de terra devido aos interesses fundiários. E, depois que a FUNAI iniciou estudo sobre as origens étnicas do grupo na década de 1980, tiveram que conviver ainda com os questionamentos identitários feitos de fora para dentro do Carretão.

Nos diferentes momentos em que estivemos com os professores Tapuia na UFG, lecionando de 2007 a 2009 na licenciatura em Educação Intercultural ${ }^{1}$ e depois em outras ações na comunidade, ouvimos relatos destes em que eles e outros Tapuia se sentiam em desconforto com sua situação etnocultural e linguística, muitos se sentiam com vergonha (ou já sentiram vergonha) de assumir que eram indígenas, que eram Tapuia, se questionando sobre sua indianidade. Nesse contexto de cobranças identitárias que parece começar no final do século XX, a proposta de aprenderem uma língua indígena (de seus antepassados) surge entre eles, sendo discutida e defendida por muitos numa tentativa de se enquadrarem em um modelo mais tradicional de comunidade indígena.

Entendemos que esses relatos demonstram uma insegurança étnica e linguística em decorrência de um processo histórico de colonização etnocultural e linguística que persiste nas cobranças e dúvidas sentidas diariamente pela comunidade, apesar de seus laços históricos com os indígenas ali aldeados e de pesquisa antropológica realizada por funcionária da FUNAI (LAZARIN, 1980) que confirmam sua descendência indígena. Uma insegurança que aos poucos constituiu o conflito identitário (ser ou não ser indígena) e o conflito linguístico (aprender ou não uma língua de seus antepassados), forjados entre os Tapuia.

Entretanto, a partir de 2012, quando passamos a participar das Etapas de Estudos do curso Educação Intercultural da UFG na

1 * Doutora em Letras e Linguística pela UFG. Professora do curso de Letras da UEG em Anápolis, Goiás. mariadelurdesnazario@gmail.com. O curso de Educação Intercultural iniciou-se em 2007, e de 2007 a 2014, 16 Tapuia entraram na licenciatura, sendo quase todos professores na Escola Estadual Indígena Cacique José Borges, ocorrendo 3 desistências do curso. Esta escola foi fundada em 2004, com a atuação somente de professores indígenas até 2016, quando uma professora branca passou a fazer parte do corpo docente. Antes dessa escola estadual, a Secretaria Municipal de Educação de Rubiataba mantinha, desde 1972, uma ou duas salas de aula para atender à primeira fase do ensino fundamental. 
Terra Indígena, contribuindo com o Comitê Orientador Tapuia², verificamos que, apesar dos questionamentos e conflitos citados ainda ocorrerem, os Tapuia viviam um outro momento, defendendo sua identidade indígena abertamente e o português tapuia como sua língua materna (RODRIGUES, 2011), problematizando e/ou refutando os questionamentos que lhes eram (e ainda são) feitos com base no discurso da não indianidade. Compreendemos que as diferentes práticas pedagógicas interculturais vivenciadas pelos professores Tapuia e sua comunidade, bem como as pesquisas desenvolvidas por eles desde 2007, quando a primeira turma de docentes Tapuia iniciaram a licenciatura em Educação Intercultural, tiveram um papel fundamental nesse processo de ressignificação identitária.

Para discutir qualitativamente as atitudes etnolinguísticas do Tapuia nos utilizamos de um corpus bastante diversificado, constituído durante pesquisa de doutoramento ${ }^{3}$, como: diários de campo; entrevistas feitas com os Tapuia, fazendeiros e posseiros em 1980 e 1983, publicadas em Almeida (2003); textos orais e escritos produzidos pelos professores em situação de formação acadêmica (monografias, reuniões de orientação, aulas); entrevistas individuais feitas com esses professores; relatórios do Comitê Orientador Tapuia.

\section{A Educação Intercultural}

O curso de licenciatura em Educação Intercultural ${ }^{4}$ do Núcleo Takinahakỹ de Formação Superior Indígena da UFG se iniciou em 2007, e sua proposta pedagógica pressupõe a implementação de uma educação como prática de libertação de um padrão de consciência da estrutura dominante, nos termos de Paulo Freire (1987).

2 O Comitê Orientador Tapuia é composto de professores do Núcleo e/ou de outros institutos e faculdades da UFG, sendo sua função orientar os professores nas etapas de estudo em Terra Indígena (geralmente em abril/maio; outubro/novembro) e na UFG (janeiro/fevereiro; julho/agosto) de cada ano, durante os 5 anos de formação.

3 Desenvolvi pesquisa de doutoramento sobre a atitude etnolinguística da comunidade Tapuia de 2012 a 2016 (NAZÁRIO, 2016).

4 O curso divide-se em uma Matriz de Formação Básica e três Matrizes de Formação Especifica, na qual o aluno pode se especializar em: Ciências da Natureza, Ciências da Cultura ou Ciências da Linguagem; a primeira com 2 anos de duração e a segunda com 3 , totalizando os 5 anos de graduação. 
Em concordância com essa finalidade, os eixos de sustentação do PPP (2006) do curso são a diversidade e a sustentabilidade, pensando na diferenciação étnica e cultural, bem como na sustentabilidade social, cultural, linguística e econômica dos povos indígenas (PIMENTEL DA SILVA \& ROCHA, 2006), colocando no centro desse projeto político e pedagógico os sujeitos índios que ficam invisibilizados do outro lado da linha (SANTOS, 2007). Nesse sentido, os princípios curriculares da licenciatura não poderiam ser outros a não ser a interculturalidade e a transdisciplinaridade.

Esses dois princípios pressupõem uma educação dialógica entre pessoas, grupos, conhecimentos, áreas do conhecimento, não só reconhecendo (PIMENTEL DA SILVA \& ROCHA, 2006), mas valorizando e construindo um diálogo intercultural enriquecedor, na UFG e na comunidade, em que de fato os conhecimentos e as identidades das comunidades (indígenas) sejam protagonizados. Assim, para além de definir uma posição teórica para lidar com a diferença no curso Educação Intercultural, tais princípios são concebidos como uma postura educacional e uma atitude metodológica (PIMENTEL DA SILVA \& ROCHA, 2006), pensando na prática educacional.

A formação do professor indígena na Educação Intercultural se dá contextualizando sua realidade e as demandas de seu povo tanto, ao vivenciarem diferentes ações pedagógicas, como: temas contextuais $^{5}$, estudos complementares, projetos de pesquisa, estudos em terras indígenas, práticas educacionais (ou prática como componente curricular - informática, inglês intercultural, português intercultural e línguas indígenas), projetos extraescolares, estágios pedagógicos e oficinas e exposição de material didático (PPP, 2006).

Ao realizar essa formação, o Núcleo Takinahakỹ procura produzir um diálogo enriquecedor com conhecimentos que tenham sentido na vida dos alunos, promovendo a sua compreensão do

5 Em decorrência do princípio da transdisciplinaridade, a licenciatura em Educação Intercultural trabalha então com a proposta de temas contextuais, que se configuram como momentos de discussão da realidade, de uma situação ou problema que possibilite ao aluno compreender de maneira abrangente essa realidade, justamente por não querer vê-la por um único prisma ou visão, mas por diferentes visões que se complementam, dando a ele uma compreensão mais acurada e problematizadora do tema, o qual, sendo visto como uma realidade importante a ser conhecida, contextualiza-se no mundo do aluno. 
contexto histórico, social, étnico e político em que vivem, a fim de contribuir para o desenvolvimento de projetos de sustentabilidade cultural e econômica nas comunidades indígenas. Nesse sentido, a busca pelo fortalecimento da autoestima desses alunos e de sua comunidade é fundamental para que juntos atuem em defesa de suas particularidades como algo de muito valor, problematizando e questionando a imposição cultural que vem de fora.

\section{Interpretando as atitudes etnolinguísticas dos Tapuia}

Durante nossa vivência com os Tapuia, identificamos um tempo quase sempre referido pelos Tapuia, no passado, de insatisfação, de falta de tranquilidade por conta das cobranças e das dúvidas em relação à sua identidade, da vergonha em se assumir, da baixa autoestima, e, especialmente, da falta de argumentos para combater tudo isso, ou seja, da falta de mecanismos de defesa de sua identidade e de sua autoestima.

Entretanto, considerando o argumento de Paulo Freire de que "todo ser se desenvolve (ou se transforma) dentro de si mesmo, no jogo de suas contradições.” (1987, p. 57), entendemos que o Tapuia, com o movimento de conscientização de suas contradições, que se iniciou por meio das ações dos professores em formação na licenciatura em Educação Intercultural, tem modificado sua realidade com o objetivo de mudar a situação de autodesvalia descrita acima.

Essa transformação já se inicia com os vínculos fortes estabelecidos com outros povos indígenas desde 2007, apesar dos conflitos vividos com alguns parentes que questionam também sua identidade étnica e linguística, e o envolvimento com o movimento indígena (participando de encontros, palestras, dando palestras) que antes parecia mais distante da realidade do professor Tapuia no trabalho de fortalecimento e defesa da identidade de seu povo. De maneira que, por meio da convivência com seus parentes na licenciatura, o Tapuia já sente uma mudança:

E a partir do momento que a gente teve esse contato com outros povos diferentes... totalmente diferentes... sete etnias diferentes dentro da licenciatura... aí eu aprendi a ser tapuia por quê? porque eu via os outros índios lá defendendo a identidade deles e eles faziam muito bem... então eu aprendi também... (Prof. Welington, p. 12). 
Esse contexto de formação, em que há um encontro com diferentes realidades étnicas, é um elemento em si formador de uma consciência de cada grupo indígena e de uma coletividade sobre a realidade política e educacional dos povos indígenas brasileiros. De maneira que podemos dizer que os impactos gerados na vida desses professores e de suas comunidades por meio de sua formação e sua ação são bastante específicos e relacionados ao contato entre essas etnias, à convivência étnica, ao diálogo entre povos diferentes, mas semelhantes em suas demandas e conflitos sociais.

Por outro lado, os professores Tapuia são unânimes em dizer que tudo mudou mesmo entre eles ou começou a mudar quando se voltaram para a comunidade por conta do projeto de pesquisa extraescolar Sustentabilidade Ambiental e Linguístico-Cultural ${ }^{6}$ e das atividades do estágio supervisionado realizado na escola da comunidade. Essas ações foram um marco divisor na sua formação e, também, na maneira de o Tapuia olhar para a sua realidade.

Iniciando, então, esse projeto no Carretão em 2009, a professora Eunice Rodrigues formula, em seminário na UFG, perguntas que traçam outros rumos para os conflitos identitário e linguístico a partir daí, as quais foram: A língua é o único fator de identificação de um povo? O que vocês entendem (ou o que vocês querem entender) por língua indígena? (REZENDE, [s.d.]b). Essas questões vinham sendo levantadas entre eles, em seminários e no

6 Os projetos extraescolares desenvolvidos nas matrizes específicas da licenciatura, quando o professor indígena já escolheu uma área para se especializar, são desenvolvidos na comunidade sob a orientação do Comitê Orientador de cada etnia. Quando essa atividade se inicia no terceiro ano do curso, os alunos já vivenciaram nos dois primeiros anos uma formação teórica, política e problematizadora tendo como temas contextuais questões e problemas que se apresentam na realidade dos povos indígenas prementes de discussão e conscientização. A partir das demandas de cada povo, esses projetos então são definidos pelos professores indígenas junto com a comunidade e têm por finalidade "envolver jovens e crianças [adultos, anciões] em atividades que contribuam com a autoestima dos participantes, assim como com a melhoria de vida." (PPP, 2006, p. 63) de todos na aldeia. Das pesquisas desenvolvidas dentro do Projeto Extraescolar de cada etnia, os alunos produzem conhecimentos sobre sua realidade, os quais são fonte de pesquisa para a realização das práticas educacionais (oficinas, seminários e confecção de material didático) e do estágio supervisionado, pois são dessas pesquisas que os professores indígenas selecionam os temas contextuais para as aulas de estágio. 
tema contextual Línguas da Região Araguaia-Tocantins na UFG e na aldeia, se fortalecendo a cada encontro e discussão.

Com essas indagações para seus parentes indígenas de outras etnias no seminário, tal professora Tapuia se situa dentro do processo histórico de luta e resistência do seu povo que perdura desde as primeiras décadas do século XX, mas formulando ainda perguntas que materializam a resiliência que vem se forjando nas práticas sociais desse grupo nesse momento. Um grupo que tem agido em busca de tomar o controle, de assumir uma autonomia diante do conflito vivido por sua comunidade, diante da adversidade, sendo capaz de enfrentá-la e sair fortalecido. Isto é, age como um sujeito histórico enfrentando as exclusões e tentativas de aniquilamento sofridas. A professora Eunice Rodrigues coloca-se resilientemente no enfrentamento das cobranças e do preconceito sofrido por todos no Carretão com o apoio dos demais professores que estavam também em formação (Márcio de Jesus, Maria Aparecida de Lima, Silma Costa, Welington Brandão, Aparecido de Aguiar, Adriana da Silva, Luís Vieira e Cândido de Lima).

Esse pensamento aguerrido percebido na fala da professora significa, em nossa compreensão, o despertar para uma atitude decolonial porque os Tapuia estavam desvelando de vez a sua situação de opressão (FREIRE, 1987; MALDONADO-TORRES, 2008), que desde o final do século XX e início do XXI se mostrava muito forte para as novas gerações no Carretão, as quais não tinham muita compreensão de suas diferenças étnicas e linguísticas e da história de seu povo no contexto do Carretão.

Não é difícil imaginar a força da violência sofrida por toda a comunidade considerando os interesses fundiários durante o século $\mathrm{XX}$, quando os anciões desde o início desse século, em sua juventude, viveram episódios de perseguição, violência física e psicológica, morte e perigo de morte no Carretão em função da questão da terra. O silenciamento, uma estratégia fundante dos governos nas políticas indigenistas antes de 1988, também foi aliado daqueles que oprimiram os Tapuia nesse tempo, por décadas, contando com a sua invisibilização étnica e seu silêncio.

Nesse contexto, silenciar-se sobre sua história também foi uma estratégia em muitos momentos dos próprios Tapuia em função do medo pelas violências sofridas desde 1920, década da primeira invasão de suas terras por um fazendeiro. Um dos professores relata essa situação como um conflito que os seus pais e avós viveram no 


\section{Carretão:}

as pessoas tinham... tiveram que arrancar de dentro deles aquela ideia de ser índio ((ruídos)) pra poder sobreviver ((ruidos)) se ele naturalizasse aquela ideia na cabeça ele não ia ter apoio... não ia ter um trabalho... porque se ele fosse trabalhar um dia lá pra alguém pra ganhar o recurso de um dia pra cuidar da família... a pessoa... "não aquele cara lá não está com nada não"...

[...]

então o que que as pessoas do entorno ... tinham dinheiro e que estavam se apropriando daqui e aproveitando ... achavam ... "não" ... que as pessoas que tem isso na cabeça iam trazer ((ruídos)) consequência pra eles ((ruídos))

[...]

Entendeu... "não ... vai trazer consequência pra gente”... "ele tem aquela ideia na cabeça de que 'não sei o que ... língua indígena'... isso depois vem polícia, não sei o que”... então ... espanta ele daqui ... então as pessoas eram como se fossem discriminadas ... ai tinha uns que tinham a questão da língua indigena ... mas ficavam calados [com] aquilo ... é você... né ter aquilo só pra você mesmo ... ((ruídos)) QUANDO... nós já passamos a ter o poder do grito ... da voz ativa e de você poder lutar por seus objetivos ... [mas] ainda tem pessoas que vivem a vida confusa ... então a... aí está amadurecendo novamente ... é uma construção de uma nova identidade ... ((ruídos)) então por isso essa discussão ... esses conflitos vão surgindo... (Prof. Márcio, p. 9-10).

Esse relato faz referência a duas realidades vividas, a de intensa opressão e a de luta para impedir que isso perdure. Como compreende Hinkelammert (1998), o sujeito se faz sujeito enfrentando-se, enfrentando seus dilemas, e faz isso confessando sua presença, gritando, tendo uma voz ativa, lutando por essa voz, por querer reivindicar sua vida, como tem feito o Tapuia. A fala da professora Eunice para o auditório cheio no seminário de sábado na UFG, em 2009, é esse grito do Tapuia exposto pelo professor Márcio, colocando-se presente no enfrentamento.

As temáticas de pesquisa dos trabalhos específicos de cada professor realizados dentro do projeto extraescolar desenvolvido nos últimos três anos de formação, materializam também essa atitude com a qual enfrentam e defendem sua identidade, colocando-se no confronto com a certeza do estereótipo indígena lançado sobre eles, que fortaleceu o surgimento de dúvidas sobre o que são, indiciando uma mudança na sua maneira de olhar para sua realidade e sinalizando 
novas estratégias de defesa de sua identidade que eles elaboraram a partir de suas pesquisas. Os resultados desses estudos realizados no contexto do projeto extraescolar foram explorados por meio de temas contextuais (como Mitos Tapuia, Território Tapuia, Comercialização, Cultura, Roças Comunitárias Tapuia, Fauna Brasileira, Classificação Cultural das Palavras) no estágio supervisionado e apresentados em seus trabalhos de conclusão de curso:

- Processo sócio-histórico de formação do Português Tapuia (RODRIGUES, 2011) de Eunice da Rocha Moraes Rodrigues;

- Narrativas tradicionais do povo Tapuia (COSTA, 2011) de Silma Aparecida da Silva Costa;

- Adornos corporais, pintura corporal e a dança tradicional Tapuia (BRANDÃO TAPUIO, 2011) de Welington Vieira Brandão;

- As nascentes da terra indígena Tapuia: importância e preservação (SANTOS, AGUIAR \& JESUS, 2011) de Ana Cristina Kawinam dos Santos ${ }^{7}$ Aparecido Caetano de Aguiar e Márcio José de Jesus;

- As atitudes linguísticas dos Tapuia em relação ao seu monolinguismo em português (LIMA, 2012) de Maria Aparecida Ferraz de Lima;

- Práticas escritas interculturais na comunidade Tapuia do Carretão - GO(VIEIRA-TAPUIA, 2012) de Luiz Antônio Vieira;

- Constituição Lexical do Português Tapuia (SILVA, 2012) de Adriana Rosário da Silva.

- Plantas Medicinais do Território Tapuia (FERRAZ DE LIMA, 2013) de Cândido Borges Ferraz de Lima.

Toda essa prática de pesquisa e problematização do ser Tapuia no Carretão e das demandas da comunidade possibilitam ao Tapuia

7 Professora Karajá, esposa do Tapuia Márcio José de Jesus, que também fez a licenciatura em Educação Intercultural e, por morar no Carretão, desenvolveu o projeto extraescolar junto com seu marido. 
outras condições de viver com seus conflitos, ressignificando sua identidade por meio de seus discursos e suas práticas que reelaboram suas estratégias ao fortalecer sua cultura (dança, pintura, adornos), inventar sua língua indígena (o português tapuia), documentar e valorizar suas tradições (festas, canções e contação de histórias), produzir, documentar, valorizar e reformular conhecimentos sobre sua realidade social, linguística e ambiental (diferenças lexicais do português tapuia; usos e funções da escrita no Carretão; a atitudes da comunidade em relação ao uso do português; hábitos alimentares; preservação das nascentes), promover novas práticas pedagógicas na escola durante e depois do estágio supervisionado e trazer para dentro da escola os conhecimentos e práticas culturais da comunidade.

O poder simbólico dos novos discursos e das novas práticas sociais e culturais no contexto da aldeia/escola local é muito significativo e profundo, porque o professor Tapuia ao se colocar como protagonista de sua própria história, ao falar de suas demandas primeiro com os seus (anciões, adultos, jovens), fora e dentro da escola, em função de suas pesquisas na aldeia e do estágio, aqueles que sentem a mesma realidade, assume "uma posição em que procura conhecer" (DUSSEL, 2012, p. 435) em comunhão com seus parentes.

Com a produção de novos conhecimentos e novas práticas sociais, culturais e pedagógicas na escola e na comunidade, a revisão dos discursos que o outro formulou/formula sobre os Tapuia, as crenças, os mitos e os sentimentos inferiorizantes em relação à sua identidade são problematizados, são questionados em sua dita verdade. Nesse caminho, os professores problematizam o habitus (BOURDIEU, [1979] 2013) em que vivem e por meio de suas pesquisas e novas práticas fazem um "trabalho de reapropriação" de si enquanto sujeitos livres (BOURDIEU, 2004, p. 28), com:

- as práticas de letramento intercultural vivenciadas na Educação Intercultural (REZENDE, [s.d.]b). Os Tapuia vivenciaram diversas práticas interculturais de letramento. Algumas resultaram em publicação: Roça Tapuia (COSTA \& REZENDE, 2013), Sustentabilidade Ambiental e Linguístico-Cultural na comunidade Tapuia do Carretão-Goiás (REZENDE, NAZARENO \& FREITAS, 2014), Caminho se faz caminhando (COSTA, 2015), entre outras; 
- a apresentação dos projetos de pesquisa na UFG para outras etnias e na aldeia para sua comunidade, e depois a defesa dos TCC para a comunidade na aldeia;

- a nova postura dos professores que se formaram, agindo com mais autonomia diante das imposições da SEDUCE, em função das exigências de se cumprir uma matriz curricular que não contempla de fato as demandas sociais, culturais e políticas da comunidade;

- aulas diferenciadas e problematizadoras com temas contextuais advindos da realidade Tapuia;

- a entrada dos anciões e intelectuais na escola nas aulas de alguns professores, com a valorização de seus conhecimentos;

- a produção de materiais didáticos sobre os Tapuia e seu uso na escola;

- o uso desses materiais entre outros que levam novas vozes para a escola ${ }^{8}$;

- a pintura corporal, as apresentações de dança fortalecidas (especialmente em eventos fora da aldeia);

- a valorização do português tapuia no contexto escolar;

- a construção de outros lugares de fala e de luta.

Entendemos que, ao começarem essas mudanças em sua realidade, o desejo de se autodeterminarem aparece fortalecido porque sua identidade estava se fortalecendo, sendo valorizada. Nesse caso, quando se trata de se ver e se sentir um Tapuia, chegando a dizer eu sou Tapuia, compreendemos que há hoje o fortalecimento de um sentimento positivo, um "desejo" em se assumir e se orgulhar desse assumir, não que não haja insegurança (geradas pelas dúvidas e conflitos), observadas em afirmações do tipo “o povo Tapuia já não tem tanta vergonha de assumir que [é] povo indígena... que fala uma língua indígena ... o português Tapuia" (Profa. Adriana).

Entretanto, é justamente nesse entrelugar, nesse espaço entre antes ter vergonha de assumir e hoje não ter tanta vergonha mais de se assumir que as atitudes etnolinguísticas desse povo encontra condições de estar se fortalecendo, fazendo com que aquele tempo de vergonha e baixa autoestima esteja em superação.

8 É preciso registrar que no Estado de Goiás não há por parte da SEDUCE de Goiás distribuição de material didático específico para as escolas indígenas. 
Hoje, como vemos nos relatos abaixo, o Tapuia fala de outra realidade daquela após entrada da Funai na aldeia, quando são fortemente questionados sobre sua identidade étnica e linguística:

então as pessoas hoje com... com o estudo elas começa ah... ah... ver o povo Tapuia... começa a entender a conhecer uma outra etnia também né... então falar mais se... se tem os... os Karajá () que não... não fala o... o... não tem uma língua e eles não... não tem vergonha de assumir então pra quê que eu vou ficar com vergonha também né... eu sou Tapuia não é porque eu não falo uma... uma Língua Indígena que eu não sou Tapuia... então... hoje... hoje você pode chegar em qualquer jovem ai oh... a maioria assim não vou falar $100 \%$ porque às vezes tem uns...mais você pode chegar no jovem... todo mundo assume tem aquela... aquela liberdade aquela... aquela... aquela... aquela... aquele desejo assim de... de... de falar assim pra você... eи... eи sou Tapuia... eu... eu moro na aldeia lá dos Tapuia... os que está estudando lá em Goiânia você pode [ir] lá conversar com eles e fala... "não... eu sou Tapuia... eu moro lá na aldeia" assim... então todo mundo tem...assim... criou essa... esse desejo de assumir... de falar que é Tapuia né... então que antigamente eh... se/... ah... eu lembro que você podia... ia na cidade assim ai perguntava "você mora aonde?”... "Ah eu moro ali... lá perto do Varjão" que a... que é depois que sai aqui dos Tapuia né. (Prof. Luiz).

As pessoas as que... até mesmo convivem... que você chega a uma pessoa que é Tapuia que mora lá em Rubiataba... que às vezes nasceu... criou... com pouco tempo que mora lá e já fala "não... eu sou Tapuia" e tal ((ruidos)) então... a gente renasceu esse orgulho das pessoas e a gente só percebe dessa forma... a pessoa não ter uma vergonha de falar que ele... quem ele é...

[...]

De primeiro... "não... eu moro no Varjão... moro não sei aonde... moro..." arrumava outro nome... ele não morava aqui dentro não... (Prof. Márcio, p. 12)

todo mundo hoje já tem orgulho de falar... chegar em uma cidade qualquer e falarem "ah... você é de onde?" ... não... eu sou lá da... da... da aldeia de índios... sou lá dos Tapuias... a gente graças a Deus ... conseguimos colocar na cabeça da comunidade o que realmente somos... através da construção do PPP também... esse PPP nos deu um ensinamento grandiosíssimo também com relação à questão cultural. (Prof. Welington, p. 13).

E, ao procurarmos compreender essa transformação na comunidade, entendemos que seu início tem relação com o processo 
de conscientização da sua história de formação e de formação do português tapuia, uma história contada e recontada na comunidade que deixou muitos Tapuia mais tranquilos consigo mesmos, sendo continuamente fortalecida nas demais ações desenvolvidas na e com a comunidade a partir do projeto extraescolar (conversas e entrevistas com os anciões, adultos e jovens; reuniões com a comunidade na escola; apresentação dos projetos de pesquisa à comunidade; pesquisas nos textos de antropólogos que estudaram a história da comunidade, entre outras) e do estágio na escola (aulas interculturais; oficinas; reuniões com os professores da escola, entre outras) e das práticas interculturais de letramento (produção de relatórios de pesquisa, de material didático, de planos de ensino, de cadernos de reflexão do estágio, de textos diversos, da monografia, entre outras) vivenciadas pelos professores, as quais, conforme a professora Tânia Rezende, "potencializaram o processo de assumência da identificação linguístico-cultural do Povo Tapuia do Carretão" (REZENDE, [s.d.]a).

Disso compreendemos que o sujeito Tapuia, estando nessa prática social de narrativização (HALL, 2000) de sua história, convocado e decidido a assumir (assumência) posições, também investe nessas posições fortalecendo sua identidade, o sentimento de pertencimento à sua identidade indígena histórica. Como nos explicou a professora Silma, ao indagarmos como foi viver com os questionamentos identitários na licenciatura, o recontar de sua história foi fundamental para rebater o discurso da não indianidade, porque em suas palavras fez com "que a gente mesmo entendesse a nossa história melhor pra poder passar pros outros né..." (Profa. Silma, p. 8). Como afirma ainda esta professora, "a nossa identidade está na nossa história" (Profa. Silma), sentindo-se segura com o fenótipo afroindígena e o uso do português tapuia, sentindo-se, a partir das explicações históricas, com os pés no chão como compreende outro professor (Prof. Aparecido).

A assumência, entendemos, é uma postura que nos remete a uma atitude constituída de novas representações, como os conhecimentos construídos, crenças forjadas no contexto do repensar de sua história e das práticas educacionais, sociais e culturais que começaram a ser realizadas e/ou fortalecidas na aldeia, possibilitando outro sentir e outro agir em relação ao ser Tapuia no Carretão. O conflito com sua identidade passa então por um reexame porque as pessoas não se sentem mais como antes, tão discriminadas 
e sem compreensão dos elementos da discriminação, já que novos esquemas foram incorporados em sua consciência (BOURDIEU, [1979] 2013).

À medida que foram conhecendo sua história e a compreendendo, que foram eles mesmos narrando sua história entre eles e de dentro para fora do Carretão, no curso da Educação Intercultural e nos encontros com indígenas e não-indígenas fora da aldeia, que foram se reconhecendo como indígenas na sua diferença por meio de seu discurso, das práticas sociais e culturais na escola e na comunidade, conseguiram se autodeterminar, se autoafirmar Tapuia, uns mais outros menos, assumindo-se como um povo diferente, descendente de índios e negros, reconhecendo a descendência africana como constitutiva da sua identidade, como uma diferença valorativa e que está presente nos hábitos culturais (BRANDÃO TAPUIO, 2011) e alimentares (COSTA, 2011) e também na língua (contribuições lexicais) (RODRIGUES, 2011; SILVA, 2012).

E com o tempo puderam explicar sua história porque a compreendiam a fim de que o outro conhecesse sua origem étnica, ao invés de ficar contando histórias que não se contextualizavam no seu mundo para eles, como se precisassem justificar sua identidade indígena, ou seja, provar o que é, a exemplo do que ocorria na UFG durante os dois primeiros anos do curso (Matriz Básica) diante dos questionamentos de seus parentes (Profa. Silma).

Os resultados da política de invisibilização, de apagamento das culturas e saberes indígenas foram tão profundos que as gerações mais novas dos Tapuia no final do século XX viviam um estado de desconhecimento da própria história do território de seus antepassados, dos troncos indígenas (Xavante e Kayapó). Apesar de terem vivenciado um momento de retorno e invenção de práticas culturais perdidas depois da entrada na Funai na aldeia, não compreendiam de fato os elementos históricos que forjaram o surgimento do Tapuia no século XIX, muito menos o contexto político de exploração em que viveram seus pais e avós por todo esse século.

Os Tapuia sentem também que há uma maior aceitação por parte do outro por terem conseguido se autodeterminar Tapuia, com uma diminuição do preconceito e da discriminação, seja porque muitos Tapuia não se veem mais com os mesmos olhos, como diz o professor Aparecido, ao afirmar não se sentir mais baixo que ninguém, como se sentia antes, pois não se vê "mais com aqueles olhos de antigamente" e compreender "que até as próprias comunidades mudaram... eles veem a gente com outros olhos também”; seja 
porque, ao se autodeterminarem com confiança, já colocam uma barreira para o outro que discrimina e age com preconceito.

Em qualquer uma das situações entendemos que o Tapuia vive uma transformação em busca de ser ele mesmo com liberdade de ser, se descolonizando de um padrão de consciência que o fazia se sentir humilhado como nos disse o professor Aparecido; não porque não há padrões, imposições, uma ordenação, suas incertezas, mas porque muitos aprenderam e outros estão aprendendo a se desvencilhar de ideias, mitos, crenças e sentimentos que os aprisionam a uma situação de conflito que os diminui, inferioriza, passando a valorizar suas diferenças históricas, havendo o que Bhabha (2013) chama de "a percepção renovada das diferenças", ao vê-las não mais como aquilo que os desqualifica, que os exclui.

Se antes havia forte na comunidade uma cumplicidade com esse discurso, com esse poder simbólico (BOURDIEU, [1979] 2013, p. 52), hoje os Tapuia têm se reconhecido e se fazem reconhecer por meio de sua prática social, cultural e discursiva. De maneira que, na compreensão dos professores, seu povo em geral hoje passa então a defender o que é, o que tem, defendendo sua identidade própria e única:

[sobre o conflito em aprender ou não outra língua] $A h . .$. [ele pensava assim] "se eu aprender xavante eu ensino os parentes... pelo menos meus filhos eu [vou] ensinar pra... nós temos que ter alguma coisa que diferencie”... mas a gente não percebia que nós... o ser Tapuia mesmo já era o diferencial [...] quer dizer... o índio Tapuia já era diferente... (Prof. Welington).

[...]

Quer dizer... o índio Tapuia já era diferente... então... mas assim... até com o enfraquecimento da identidade mesmo na época né... eu não sabia defender essa identidade Tapuia... (Prof. Welington, p. 11).

[...] porque antes igual eu falei ((ruidos)) os caciques... as pessoas que saíam fora... ficavam... tentando trazer as coisas do outro pra dentro da nossa comunidade não é?

[...]

A gente tem que aceitar que é diferente e pronto! (Profa. Eunice, p. 22).

[sobre o novo PPP] a gente está analisando a forma de ensino... está valorizando... as diferenças que têm [no] Carretão... as diferenças dos troncos não é? É... valorizando as diferenças de fala do Carretão... as diferenças de costume... (Profa. Eunice, p. 24). 
Disso entendemos poder dizer que vivem um momento em que suas diferenças estão deixando de serem vistas como negativas porque os excluem para serem vistas como algo que pode ser celebrado porque enriquece sua identidade (WOODWARD, 2000), sendo a partir delas que muitos se sentem confiantes para se autodeterminar. Hoje, a partir das ações desenvolvidas na aldeia/ escola, estão mudando cada vez mais sua consciência, suas crenças e seus sentimentos em relação a sua identidade única, vendo-a/ aceitando-a como aquilo que fortalece o seu povo ser identificado como grupo indígena do Carretão, por entender ainda que, devido às condições de subjugação no aldeamento e as práticas de colonização, não teriam outra possibilidade de ser e existir.

Nesse contexto, a questão sociolinguística também é um dos componentes dos discursos formulados pelos Tapuia, como pelos de fora da comunidade, considerando a afirmação de sua identidade indígena. Nesse aspecto, os resultados dos trabalhos desenvolvidos especialmente pelas professoras Eunice Rodrigues (2011) e Adriana Silva (2012) foram fundamentais nessa discussão.

A argumentação tecida pela professora Eunice Rodrigues de que a língua materna de sua comunidade sempre foi o português, uma língua que, no contexto de multilinguismo de Pedro III, recebeu contribuições das diversas línguas formadoras, as quais levam a professora-pesquisadora a categorizá-lo de um português diferenciado, o português tapuia, promove o conhecimento sobre a história sociolinguística de seu povo. Em sua defesa afirma:

As reminiscências do passado conferem ao português,
ainda hoje falado pelos Tapuia, um colorido e
uma melodia especiais, tornando-o um português
matizado pelas línguas indígenas, mesmo que elas
sejam apenas línguas reminiscentes (cf. DUNK-
CINTRA, 2005; 2008) ou línguas de longínquas e
quase silenciadas lembranças (cf. SANTANA, 2012).
Tudo isso faz desse português um Português Tapuia,
portanto, uma língua indígena, a língua dos indígenas
Tapuia. (RODRIGUES, 2014, p. 14).

Nesse contexto de afirmação étnica, já com uma atitude positiva em relação ao ser Tapuia e a sua língua materna, o português tapuia, a professora assume ainda uma postura política ao dizer que este é a sua língua indígena, já que é a língua do seu povo. A clareza 
de seus argumentos relacionando essa realidade à política linguística do monolinguismo no Brasil é muito importante porque politiza essa identidade ao deixar claro que o português como língua materna da comunidade faz parte de um projeto histórico de colonização linguística do qual seus antepassados não puderam escapar.

Pensando no português diferenciado denominado de português tapuia (RODRIGUES, 2011), a pesquisa da professora Adriana Silva Constituição Lexical do Português Tapuia (2012) reforça a defesa de Eunice Rodrigues de que a maioria dos itens "considerados tapuísmos" são de uso das famílias xavante na comunidade (REZENDE; RODRIGUES, [s.d.]), respaldando a origem léxico-cultural de base xavante na língua usada ali. Essas palavras demonstram a interculturalidade linguística em função do encontro de diferentes cosmovisões no Carretão, de maneira que o português tapuia traz em si as diferentes culturas linguísticas que estão na base da formação etnocultural do povo Tapuia, em especial, a cultura da etnia Xavante - principal e maior grupo indígena levado para Pedro III.

Sendo assim, em relação à situação sociolinguística, interpretamos que há um sentimento que foi positivado por entenderem que não precisam aprender uma língua estranha para se confirmarem indígenas, por terem a confirmação de que sua língua originária é o português e de que nunca falaram outra língua, portanto nunca perderam nada (RODRIGUES, 2011), relembrando as cobranças identitárias sofridas. $\mathrm{O}$ desejo e a própria pressão entre os Tapuia para aprenderem outra língua promoviam um sentimento de desânimo, especialmente, porque parecia uma necessidade primeira de todos eles, mas de realização muito distante.

Nesse sentido, ao discutirem diferentes conhecimentos e realidades indígenas no curso, vão percebendo que a sua situação sociolinguística era mais que comum, com outras etnias também falando somente o português e assumindo o seu jeito de falar. Passam a se ver como um povo indígena específico por conta de sua história e suas diferenças, mas também com uma história semelhante à de outros povos que não falam mais as línguas de seus antepassados (a exemplo, Tremembé - CE, Atikun - PE, Xakribá - MG), vivendo os conflitos provocados por uma colonização linguística que persiste.

No entendimento de alguns professores, seu povo agora pode discutir sobre a formação da comunidade e esclarecer porque falam português e que língua é essa: “... hoje ... a gente sabe defender 
qual língua é essa também [português tapuia], porque a gente tem esse português diferente." (Prof. Welington), sendo, por isso, que a maioria não fala mais em aprender uma língua indígena, sendo "muito difícil você ver uma pessoa falar que quer aprender [uma língua indígena]." (Prof. Luiz, p. 17).

Nesse contexto, o conflito linguístico aprender ou não uma língua indígena para se autoafirmar ganha outros elementos, configurando-se agora em outros termos já que havia muitas dúvidas se algum Tapuia antigo havia chegado a falar uma língua Macro-Jê, e sabendo que seu povo nunca falou outra língua senão o português (RODRIGUES, 2011), o aprendizado de uma "língua estranha" (Prof. Welington) deixa de ser uma necessidade para os Tapuia em geral.

Em entrevistas feitas em 2014, os professores e o cacique concordam que o desejo e/ou anseio de aprender uma língua de seus antepassados já é passado para a comunidade em geral, e eles próprios não se sentem mais compelidos a aprender uma língua indígena porque hoje entendem que a LP é e sempre foi a sua língua materna. Com isso, tal conflito não se encerra, mas fica bastante amenizado.

Olhando então para esse conflito que se relaciona com diferentes atitudes, vemos que ainda há aqueles que cogitam vez ou outra o aprendizado de uma língua indígena, mas entendemos que outras representações reconfiguram o conflito, porque há também os que dizem que não existe um português tapuia e os que defendem esse português, e, entre estes, havendo os que falam que os Tapuia têm um "palavreado diferente" (Prof. Luiz, p. 15).

Nesse contexto, há por meio da escola um movimento de valorização do jeito de falar do Tapuia, por ser a língua que ele aprendeu, a língua que tem, a sua língua mãe (LIMA, 2012), fazendo-nos perceber uma afetividade por esse falar junto com um alívio de não ter, mesmo que em tese, de aprender outra língua para continuar sendo o que sempre foi, Tapuia. Nesse contexto, assumir o português tapuia como um português diferenciado, não exatamente como uma língua indígena, não se apresenta como uma dificuldade, havendo uma atitude positiva, favorável por parte da comunidade, e os resultados de pesquisa das professoras Eunice Rodrigues (2011) e Adriana Silva (2012) são decisivos para isso, especialmente, por terem identificado diversas contribuições etnoculturais dos léxicos das línguas indígenas formadoras do português tapuia, fortalecendo a compreensão de sua identidade etnolinguística e sua valorização.

Assim a valorização do português tapuia ocorre evidentemente também pelo viés da diferença, agora celebrada por muitos na aldeia, 
por conta das palavras catalogadas em pesquisa, que representam a memória da diversidade linguístico-cultural do Carretão (RODRIGUES, 2014), como: choconó $^{9}$ (espécie de bolsa de carregar criança, redonda, feita de palha de buriti), cloá (fruta), depro (café, para algumas pessoas mais velhas), entre outras (SILVA, 2012); garapiá (planta de fumar), larai (bêbado), mexer no sheshen (fazer sexo), entre outras (RODRIGUES, 2014, p. 14), entre outras; bambé (muito), derbando (curtindo com outra pessoa, pregando uma peça, fazendo graça) (SILVA VIEIRA, FRAGA, MARTINS, CHAVES DE MORAIS, VIEIRA BRANDÃO \& BRANDÃO, 2016).

O valor simbólico desse resultado para a comunidade é profundamente importante, porque é a materialização no seu falar o português tapuia - da história linguística de seu povo, fortalecendo uma identificação com o seu passado, sendo "a expressão do sentimento de pertencimento ao ser indígena e ao ser Tapuia no Carretão" (REZENDE \& RODRIGUES, [s.d.], p. 20).

A valorização do português tapuia tem se fortalecido ainda por conta de uma crença importante que se formulou entre os professores e seus alunos de que o seu uso facilita a compreensão dos conteúdos na escola, aproxima os alunos daquilo que lhe é ensinado, sendo direito de todos aprenderem usando a sua língua materna (VIEIRATAPUIA, 2012), o português tapuia. A escola, nesse sentido, tem tido um papel importante pela autonomia em valorizar os usos linguísticos de seus alunos em sua prática pedagógica, como também de outros Tapuia com a valorização das narrativas tradicionais (COSTA, 2011) levadas para o contexto da escola nas aulas e em oficinas de contação de história durante um dos estágios do curso de Educação Intercultural, assumindo uma política linguística de valorização da língua sentida e falada por seu povo.

Evidentemente que essa valorização da diferença não se dá sem questionamentos e confrontos, pois, se, de um lado, há aqueles que valorizam o português tapuia como uma língua diferenciada, a língua com a qual eles se identificam, demonstrando uma atitude

9 Dois discentes Tapuia da turma de 2014 escreveram essa palavra com a grafia chokónon em um material didático (FRAGA \& MARTINS, 2014) produzido por eles nesse mesmo ano. Depois, em 2015, em atividade para o PIBID Diversidade/UFG da área Ciências da Cultura, os cinco alunos Tapuia entregaram um texto em que usaram a grafia xoconã (SILVA VIEIRA, FRAGA, MARTINS, CHAVES DE MORAIS, VIEIRA BRANDÃO, BRANDÃO, 2016). 
positiva em relação a ele, por outro, há os que veem o português tapuia em relação de oposição com o português padrão, sendo o primeiro visto como feio e errado, enquanto este como mais bonito e correto, como relata um dos professores:

Muitas das vezes o português Tapuia é mal visto por alguns Tapuia que dizem que é feio e sem conhecimento, enquanto o português padrão é bonito e bem visto. Essas afirmações são ouvidas principalmente de alunos que estudam fora da aldeia e também pelos pais desses alunos... (VIEIRATAPUIA, 2012, p. 12).

Hoje eu sei, com os estudos na Licenciatura Intercultural Indígena e com diálogo com a comunidade que a atitude dos Tapuias com relação ao Português Tapuia, manifestada na ideia de que o Português Tapuia é feio, pode ser quebrada, por meio do ensino, pois podemos ensinar os alunos do jeito que eles acharem mais fácil de aprender.

Hoje os alunos reclamam quando um professor ensina no português brasileiro, o aprendizado não é completo, mas quando é ensinado no português Tapuia o aprendizado é completo.

Por outro lado, há também contradições, os pais dos alunos criticam o professor, falando que este não está ensinando direito, pois têm uma concepção que o professor que ensina bem é aquele que fala o português bem falado, ou seja, o que fala o português padrão. Alguns alunos também têm essa concepção. (VIEIRA-TAPUIA, 2012, p. 12).

Essas atitudes, que são sociolinguísticas por revelarem avaliações feitas diretamente à língua usada por eles, têm uma relação direta com o valor que o português padrão como uma língua legítima, como importante capital cultural (BOURDIEU, [1979] 2013) percebido pelos que se opõem, por exemplo, ao uso do português tapuia nas aulas. No entanto, esse mesmo professor em entrevista argumenta que os alunos da escola se sentem mais à vontade quando os professores dão "aula do jeito que a gente conversa no nosso diaa-dia", chegando alguns a dizerem que, quando ele usa o português padrão em sala, está "falando exibido" (Prof. Luiz, p. 14).

De todo modo, vemos um movimento descolonizador na escola por parte dos professores, especialmente, por defenderem a interculturalidade linguística em sala de aula, posicionando-se de 
maneira mais humana ao pensarem nas relações intersubjetivas que se estabelecem em sala e, ainda mais, considerando que os alunos e os professores e demais funcionários da escola se relacionam ali como pessoas que se conhecem na intimidade, com a afetividade daqueles que fazem parte da mesma família, no caso do povo Tapuia.

Por outro lado, o professor Luiz em entrevista retoma a discussão do seu TCC e ressalta a importância de os alunos Tapuia adquirirem uma escrita padrão do português em função das exigências sociais, apesar de compreender que o aprendizado da escrita padrão continuamente, em suas palavras, "mata" a fala original da criança - o português tapuia.

\section{ALGUMAS CONSIDERAÇÕES}

Compreendemos que, em oposição à situação de opressão e de práticas de aniquilamento de sua história e identidade indígena, e, consequentemente, de seus direitos sobre a terra, as práticas sociais e culturais (re)elaboradas pelos Tapuia no contexto de formação de seus professores, promoveram as condições necessárias para os questionamentos necessários que os conduzissem a um repensar de suas contradições. Entendemos que agora eles se veem com mais autonomia em um contexto de conflitos e interesses individuais (fazendeiros/posseiros) e coletivos (povo Tapuia), de muitas contradições e muitas diferenças (étnicas e culturais), diferenças que se unem em uma identidade indígena, o Tapuia, mas, ao mesmo tempo, permanecem sendo vistas como tais em sua especificidade étnica e cultural, compreendendo-as no tempo e no espaço do território indígena, percebendo-as como algo positivo em sua identidade.

Com isso, o Tapuia sente sua identidade etnocultural e linguística fortalecida porque foi ressignificada por meio de outros discursos, novas práticas e diferentes posições assumidas na aldeia e fora dela, (re)construindo permanentemente sua realidade a partir de outra percepção dessa realidade, de forma que as atitudes desse povo em relação à sua identidade está se fortalecendo positivamente entre um fazer e outro na aldeia.

\section{REFERÊNCIAS}

ALMEIDA, R. H. (Org.). Aldeamento do Carretão segundo os seus herdeiros tapuios: conversas gravadas em 1980 e 1983. Brasília: CGDOC/ FUNAI, 2003. 
BHABHA, H. K. O local da cultura. Belo Horizonte: UFMG, 2013.

BRANDÃO TAPUIO, W. V. Adornos corporais, pintura corporal e a dança tradicional Tapuia. Monografia (em Educação Intercultural), Núcleo Takinahakỹ de Formação Superior Indígena - Faculdade de Letras, Universidade Federal de Goiás, Goiânia, 2011.

BOURDIEU, P. Coisas Ditas. São Paulo: Brasiliense, 2004. $\overline{\text { Zouk, } 2013 .}$

[1979] A distinção: crítica social do julgamento. Porto Alegre:

COSTA, S. A. da S. Narrativas tradicionais do povo Tapuia. Monografia (em Educação Intercultural), Núcleo Takinahakỹ de Formação Superior Indígena - Faculdade de Letras, Universidade Federal de Goiás, Goiânia, 2011.

. Caminho se faz caminhando. PIMENTEL DA SILVA, Maria do Socorro; BORGES, Mônica Veloso (Organizadoras). Práticas Pedagógicas de Docentes Indígenas. Goiânia: Gráfica/UFG, 2015.

COSTA, S. A. da S.; REZENDE, T. F. (Orgs.) Roça Tapuia. Goiânia: FUNAPE, 2013.

DUSSEL, E. Ética da Libertação. Na ideia da globalização e da exclusão. Petrópolis: Vozes, 2012.

FERRAZ DE LIMA, C. B. Plantas Medicinais do Território Tapuia. Monografia (em Educação Intercultural), Núcleo Takinahakỹ de Formação Superior Indígena - Faculdade de Letras, Universidade Federal de Goiás, Goiânia, 2013.

FRAGA, C. B.; MARTINS, E. C. Chokónon e Jiboia. Material Didático. 2014. (não publicado).

FREIRE, P. [1968] Pedagogia do Oprimido. São Paulo: Paz e Terra, 1987.

HALL, S. Quem precisa da identidade? In: TADEU DA SILVA, T. (Org.); HALL, S.; WOODWARD, K. Identidade e diferença: a perspectiva dos Estudos Culturais. Petrópolis: Vozes, 2000.

HINKELAMMERT, F. J. El regreso del sujeto viviente. In: . El grito del sujeto. Del teatro-mundo del Evangelio de Juan al perro-mundo de la Globalización. San José, Costa Rica: Editorial DEI, 1998.

LAMBERT, W. W.; LAMBERT, W. E. [1966]. Psicologia Social. Rio de Janeiro: Zahar, 1975.

LAZARIN, R. H. de A. Relatório sobre os índios do Carretão (1980). Ministério da Justiça. Fundação Nacional do Índio - FUNAI, 1980. 
LIMA, M. A. F. de. As atitudes linguísticas dos Tapuia em relação ao seu monolinguismo em português. Monografia (em Educação Intercultural), Núcleo Takinahakỹ de Formação Superior Indígena - Faculdade de Letras, Universidade Federal de Goiás, Goiânia, 2012.

MALDONADO-TORRES, N. La descolonización y el giro des-colonial, Tabula Rasa, Bogotá, Colômbia, n. 9, p. 61-72, jul./dez., 2008.

NAZÁRIO, M. de L. Atitudes etnolinguísticas do povo Tapuia do Carretão $(G O)$. Tese de Doutorado (Doutorado em Letras e Linguística), Pós-Graduação em Letras e Linguística, Faculdade de Letras, Universidade Federal de Goiás, Goiânia, 2016.

PIMENTEL DA SILVA, M. S.; ROCHA, L. Educação bilíngue intercultural entre povos indígenas brasileiros. Revista UFG, Ano VIII, nº 2, dez. 2006. p.100-105.

PIMENTEL DA SILVA, M. S. Impactos dos usos das línguas indígenas na formação de professores indígenas no Curso de Educação Intercultural de Formação Superior Indígena da UFG. Relatório de Estágio de Pós-doutoramento em Linguística, São Paulo, IEL, UNICAMP, 2014.

PPP - Projeto Político-Pedagógico da Licenciatura Intercultural, Universidade Federal de Goiás, Núcleo Takinahakỹ de Formação Superior Indígena, Goiânia, 2006.

REZENDE, T. F. Processos de identificação linguístico-cultural por meio de práticas interculturais de letramento. [s.d.]a (não publicado)

. Politicas linguísticas sustentadoras das práticas identitárias indígenas dos Tapuia de Goiás. [s.d]b (não publicado)

. Praticar a escrita em português intercultural com os indígenas da região Araguaia Tocantins. In: PIMENTEL DA SILVA, M. do S.; BORGES, M. V. Educação Intercultural: experiências e desafios políticos pedagógicos. Goiânia: PROLIND/SECAD-MEC/FUNAPE, 2013.

REZENDE, T. F.; RODRIGUES, E. da R. M. Português Tapuia: resistência linguística no cerrado central do Brasil. [s.d.] (não publicado)

REZENDE, T. F.; NAZARENO, E.; FREITAS, M. T. de U. Sustentabilidade ambiental e linguístico-cultural na comunidade Tapuia do Carretão-Goiás. Goiânia: UFG, 2014.

RODRIGUES, E. da R. M. Processo sócio-histórico de formação do Português Tapuia. Monografia (em Educação Intercultural), Núcleo Takinahakỹ de Formação Superior Indígena - Faculdade de Letras, Universidade Federal de Goiás, Goiânia, 2011. 
. Processo sócio-histórico de formação do Português Tapuia. In: REZENDE, T. F.; NAZARENO, E.; FREITAS, M. T. de U. Sustentabilidade ambiental e linguistico-cultural na comunidade Tapuia do Carretão-Goiás. Goiânia: UFG, 2014.

. Estágio pedagógico na escola Tapuia. In: PIMENTEL DA SILVA, M. do S.;BORGES, M. V. Práticas pedagógicas de docentes indígenas. Goiânia: Gráfica/UFG, 2015.

SANTOS, B. de S. Para além do pensamento abissal: das linhas globais a uma ecologia de saberes, Revista Crítica de Ciências Sociais, 78, outubro, p. 3-46, 2007.

SANTOS, A. C. K. dos; AGUIAR, A. C. de; JESUS, M. J. de. As nascentes da terra indígena Tapuia: importância e preservação. Monografia (em Educação Intercultural), Núcleo Takinahakỹ de Formação Superior Indígena - Faculdade de Letras, Universidade Federal de Goiás, Goiânia, 2011.

SILVA, A. Constituição Lexical do Português Tapuia. Monografia (Graduação em Educação Intercultural), Núcleo Takinahakỹ de Formação Superior Indígena - Faculdade de Letras, Universidade Federal de Goiás, Goiânia, 2012.

SILVA VIEIRA, B.; FRAGA, C. B.; MARTINS, E. C.; CHAVES DE MORAIS, L. C.; VIEIRA BRANDÃO, L. C.; BRANDÃO, W. O português tapuia na visão do povo Tapuia. Síntese do Subprojeto da Área da Linguagem/PIBID - Diversidade, Núcleo Takinahakỹ de Formação Superior Indígena - Faculdade de Letras, Universidade Federal de Goiás, Goiânia, 2016. (não publicado)

VIEIRA-TAPUIA, L. A. Práticas escritas interculturais na comunidade Tapuia do Carretão - GO. Monografia (em Educação Intercultural), Núcleo Takinahakỹ de Formação Superior Indígena - Faculdade de Letras, Universidade Federal de Goiás, Goiânia, 2012.

WOODWARD, K. Identidade e diferença: uma introdução teórica e conceitual. In: TADEU DA SILVA, T. Identidade e diferença: a perspectiva dos estudos culturais. Petrópolis: Vozes, 2000. 
